\title{
The Research On Building a Price Model for Urban Commercial Land Evaluation
}

\author{
BU Bing \\ National Earthquake Response Support Service (NERSS) \\ Beijing 100049, China \\ bubing001@126.com
}

\author{
Thanakrit Gu \\ School of Medicine \\ Shanghai Jiao Tong University \\ Shanghai, China \\ dollarside@gmail.com
}

\begin{abstract}
This essay concludes, on the basis of the theory of the increase in land value and the supply-demand curve of China's market, the incorporation of the new concept of benefit equilibrium baseline. Through comparison of earlier real estate market and land prices, analysis of urban commercial land prices and its basic model and be carried thorugh. During this process of developing a formula for the international market and redefining its definition, a formula for China's land value during this period of marketization has been achieved.
\end{abstract}

Keywords-supply-demand relati; benefits equlibirium baselin; prices commercial land

\section{INTRODUCTION}

This essay will take the idea of increase in value of land, through mathematical formulation, to derive the many implications of the supply-demand relation. Moreover, in supply-demand relation, utilizing mathematical formulas and perspectives of economics to explain China's current land market situation. This also explains the root of government views and regulations on the land value. Lastly, scientific evidence through the structural model of land value, scientific data can be provided for the future usage of commercial land.

\section{ANALYSIS OF CURRENT DEVELOPMENT}

When analyzing the differences of the normal and monopolistic supply and demand, traditional analysis emphasize on the effects on the supply-demand curve from the country and/or regulations. This kind of alteration can bring the most desirable profit elevation, but as for the rise in number of investors, the function of the demand curve would have obvious changes in values (though the demand itself is not greatly affected). On the land market, the crucial analysis is of that the effects on prices of real estate, because the number of general regulations being increased, can reposition the land market. Moreover, the funding and attention all reflect that the land market is approaching in an upward trend. Therefore, this text emphasizes on the importance of demand analysis and the model of the land market.

\section{ANALYSIS OF LAND DEMANDS AND REGULATION MODEL OF CHINA'S DEVELOPING CITIES}

Under the conditions of the market in China, the function of supply curve's increment can be converted to a curve of practical model because of the monopolistically supplied land by the government. The demand curve, however, is not valued. The changes in the demand curve is not obvious, because the function's basic properties are not altered. This is exactly the purpose essay in rearranging point of views to analyze the definition of the demand curve. The changes in the curve must have significant influence on the market.

A The significance of the change in the demand curve under the conditions of China's market

When analyzing the supply curve of the price of land, very little discussion is made on the shape of the demand curve and its derivative. As shown in figure.1, under the same condition of decreased in supply, the price in the land market is raised. But by knowing the actual profits, a relationship can be drawn. S1 is the profit caused by the rise in land prices, and S2 is the lost profit from the decreased amount of land supply, from S1-S2 the governmental regulations affected profits can be seen.

From figure.1, it can be seen that the profit scale has a close correlation with the demand curve D. Normally speaking, the rise in profits can shift the demand curve upwards but does not affect the slope of the curve itself. But the fact that this type of change occurs under the condition that market demand stays the same is ignored. However, in a practical example where the market demand does change, supply is less than demand when the curve becomes steeper. This implies that there are a large number of sellers, and there is a scarce amount of land. As the slope of the curve becomes more gradual, it implies that supply is greater than demand. This means that amount of land is great, and sellers is scarce. This type of changes depends greatly on the level of demand. 

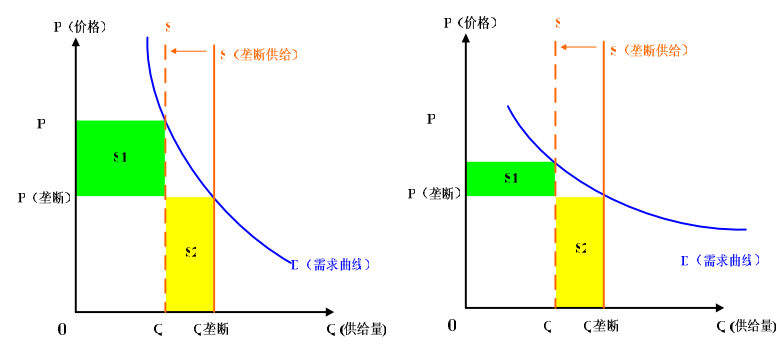

Figure.1 Benefits and costs modelbrought by the decrease in supply

As shown, when analyzing the changes of the demand, more consideration is usually put on the rise of the profit, not the change in the slope of the demand curve. Secondly, this effect on the demand curve reflects the changes in the level of the demand for land. Naturally, this includes the body of the investors and rigid requirements.

\section{B Analysis of China's Land Regulation Policies}

Recent years, the rigorous rise of urban land and real estate prices has caught the attention of strategic policy makers. Experts of this field hypothesize that the reason for such a rise is that the supply of land cannot satisfy the demands [1]. Because the shortage of supplied land, development firms will try "rob" the land at all costs. The inevitable result is the rise in the price of the land. Therefore this exemplifies the importance of how land supply can decide the price of the land ${ }^{[2]}$. However, if the idea increasing the supply of land is agreed upon, constantly requesting more land from the government, then it would not be surprising to see an increase of the amount of foam economy on the stage of the land market. In the follow up measure to regulate this foam economy is for the government to explain the employed purchase limit in the light of economic mode. Moreover, the government needs to explain how the repositioning of land value in the light of profit equilibrium. This essay proves the above by analyzing the demand curve.

Firstly, development firms have a goal of maximizing profits. In other terms, because the development of land takes up a definite amount of time, development firms need a more active market for land to shorten the period of gaining profits. Within a period with fixed supply of real estate, to extend the duration of people's enthusiasm, development firm only need to increase the amount of parties in demand to keep an active market. However, the parties demanding needs to be investors with funding. What lies before the government is a complex question of how to differentiate the two through methods of using proof of property ownership etc.

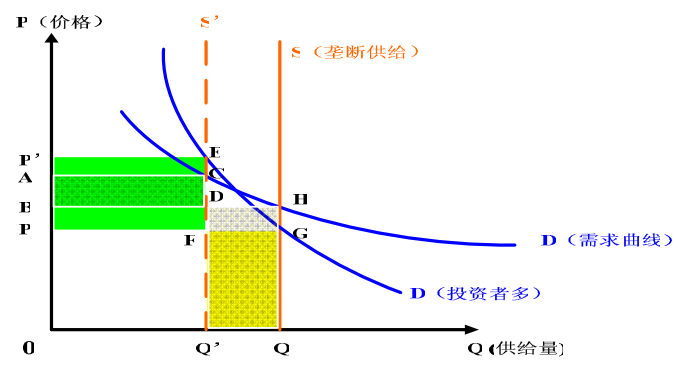

Figure.2 Real estate investment vs. the effects on the increasing prices of land

Presented in figure.2, purchase limit regulation reflects the underlying purpose of investors being as follow:

(1) Under normal conditions, as the government decrease the supply of land the drop in profits is enclosed by DHQQ'. The increased profits caused by the rise in land prices is the area enclosed by ABDC;

(2) Under the conditions in which the number of investors (speculators) is too high, the lost in profit caused by decreased number of supplied land is shown by the area enclosed by FGQQ'. Also, the area $\mathrm{S}_{F G Q Q}$, is less than the area $\mathrm{S}_{D H Q Q}$, Profit as the result of the rise in price of land is shown by the area enclosed by P'EFP, and area $\mathrm{S}_{P}{ }^{\prime} E F P$ is greater than the area $\mathrm{S}_{A B D C}$;

As shown above, practically speaking, when there is a large amount of investors and a small number of supplied lands by the government, the lost in profit will be less (though the prices of the land will increase). Development firm also satisfy investors' need for an active market. The government's department of treasury maximizes the profit, and therefore a win-win situation in this scene. On the other hand, the suppressive regulations by the government in fact are to achieve the purpose of disturbing such a scene. One effect is slowing down the increase in land supply, because land supply is limited and cannot be used as a long term solution. On the other hand, On the other hand, to adjust the demand curve (to be more gradual) would require only governmental policies. Once investors (speculators) are excluded from the purchasing body, they area of profit can be fundamentally decreased. Though this can damage the government's profits significantly, it can lower the price of land-breaking the win-win scene.

\section{Analysis of land price's profit baseline in China}

Theoretically speaking, the profit the government receives after regulation is in fact difference of the price the rise in the price of land and the decreased profit caused by the decrease in the supply of land. As shown in figure 3, the profit of the government is the difference of areas S1 and S2. The average of the damage on profits one deal brings and its profits can be used as a baseline for a transaction. This is also more commonly known as a "break even". Similarly, the government will abide by this simple "break even" principle whilst enforcing regulations and 
policies. Through the area of the graph, it can be seen that the theorized baseline of transaction $\mathrm{S} 1=\mathrm{S} 2$. This means that the profits from the rise of land prices equal the decrease in profit caused by lowered amount of supplied land. In other terms, if the unit price for the land market is lower than that, S1 determines the price, P'. Therefore, the deficits on government's profit may exist, and the allowed price baseline is $\mathrm{P}$ ' when $\mathrm{S} 1=\mathrm{S} 2$.

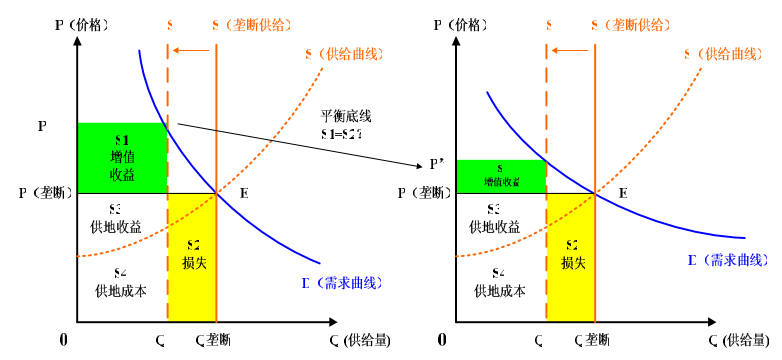

Figure.3 Government profit equilibrium baseline comparison and analysis.

But in a practical case, shown by the graph on the right of figure.3, certain areas' demand curve will become more gradual because of recent increase in number of regulations by the government. Under the conditions of decreasing the supply of land, a panic in drop of land prices may occur if loss of profits caused by the decrease in supply of land provided by the government, represented by the area $\mathrm{S} 2$, is less than the profits from the rise of land prices, represented by area $S 1^{[3]}$. This is because people realize that price $\mathrm{P}$ ' is no longer the equilibrium line for government's profits, but is now a new price, $\mathrm{P}$ '.

As described above, while analyzing the profit equilibrium, the costs and profits of supplied land are ignored. This essay purposes that the profit equilibrium should be determined by the above four means and satisfy the following formulas:

\section{S4(Costs of Supply of Land) + S2(Losses) $=$ S1 (Profits from Increase In Value)+S3(Supplied Land Profits)}

Under normal regulatory conditions, costs of supply of land and the profits from the supplied land is represented by the curve of S. Under a monopolistic condition, the supply is determined by the curve of S'. Due to the fact that the land in China is, after all, the country's property, there is a likelihood that the amount of the land the government will provide to decrease significantly. The losses will be undertaken the profits from S1 and S3. This is why when after the prices of the land drop to $\mathrm{P}$ ', it may continue to drop to $\mathrm{P}$ ', . Based on above conclusion, if $\mathrm{S} 2<\mathrm{S} 1+\mathrm{S} 3$, the prices of the land may have space for further drop. Therefore, government profit baseline $\mathrm{P}$ "' may be determined by increased profit S1 and the actual supply of land. S2, S3 and S4 may all be used on the above graph to obtain the supply equilibrium point $\mathrm{E}$.

From this, it can be seen that as of today, the rise and falls of land prices indeed never have reached the government's profit baseline. Even when the increase in profits brought by shift in land usage or shift in investments on the land are less than loss from the decreased in land supply, the government's attempts to push down the prices of land continues. Because the costs and benefits of the land have always been regulated by the government ${ }^{[4]}$, it is expected that its magnitude is ignored.

\section{PRICE MODEL OF DEVELOPING URBAN COMMERCIAL LAND}

\section{A Setup of the theoretical model}

From a demand approach, analysis concludes following causes for changes in the demand of commercial land:

1) Standard of urban income - using $y$ to represent, its increase will higher the demand of a leasehold of commercial land ${ }^{[5]}$.

2) Total amount of urban labor and population using $n$ to represent, this is an important factor on the demand for commercial land.

3) Urban joviality — represented by $a$, is dependent on the factors such as quality of environment, quality of education, and crime rate. All of these factors affect the demand for commercial land.

4) Price of noncommercial land produce (related to price of commercial land) — using $p_{x}$ to represent, its change can affect the demand in the commercial land market.

5) Commercial land price — Using $p$ to represent, this is the main source of profit.

6) Real estate mortgage interest rate and property tax rate — represented by $i$ and $t$, the momentum of these two can also affect the cost for supply of the commercial land.

7) Expected profits - Using $e$ to represent, the expected profits from by the rise in the capital of commercial land will decrease the supply of commercial land's capital. From here, the demand of commercial land can increase.

Therefore, based on these ideas, the demand $D_{\text {commerical }}$ land can be represented as the following equation:

e)

$$
D_{\text {commerical land }}=D_{\text {commerical land }}\left(p, y, n, a, p_{x}, i, t,\right.
$$

Secondly, from analysis of supply, the factors affecting the equation are not only $p, i, t, e$, but also include land prices and prices of construction materials; represented by $l$ and $c$ respectively. The rise in land prices $l$ and prices of construction material $c$ will raise the costs for commercial lands; thus, this will decrease or affect the supply of commercial land ${ }^{[6]}$. Based on the trend of long term graph of the commercial land market, the supply formula, using $S_{\text {commerical land, }}$ can be described using the following formula:

$$
S_{\text {commerical land }}=S_{\text {commerical land }}(p, l, c, i, t, e)
$$

In a market economy, demand and supply of urban commercial land present a graphical change. Under the condition when the supply equilibrium is profitable, the 
above formula for $D_{\text {commerical land }}$ and $S_{\text {commerical land }}$ can be correlated ${ }^{[7]}$. With this correlation, the formula for the price of commercial land $p$ can be written as follow:

$$
p=p\left(l, c, i, t, e, y, n, a, p_{x}\right)
$$

As seen, there are a total of nine factors which affects the price $p$ for the market of commercial land ${ }^{[8]}$. The nine factors include: land prices $l$, prices of construction materials $c$ unchanged mortgages interests $i$, property taxes $t$, expected profits $e$, urban income $y$, urban population $n$, urban joviality $a$ and price of noncommercial land produce $p_{x}$.

\section{B Mathematical expression for the model development of} commercial land prices

Through the analysis on the model of urban commercial land being done above, a formula derived to determine the practical price of commercial land $P_{\text {commerical land }}$ is formed as follow:

$$
\begin{gathered}
P_{\text {commerical land }}= \\
a_{0}+a_{1} p_{\text {land }}+a_{2} y_{a}+a_{3} s_{a}+a_{4} n+a_{5} e+a_{6} c+a_{7} a_{p}+a_{8} a_{g}+a_{9} a_{c} \\
+a_{10} a_{s}+a_{11} p_{x}+a_{12} u_{a}+a_{13} c_{1}+a_{14} c_{2}+a_{15} c_{3}+a_{16} c_{4}+u_{0}
\end{gathered}
$$

As seen in the above equation, the variable on the left side is dependent also on $P_{\text {commerical land }}$, and the variables on the right are the factors affecting the other variable on the left. These variables being looked at mathematically is the crucial point in insuring objective profitability. Below shown in table 1 are the external factors and its mathematical significance.

A point to be noted here is that, through a stable virtual regulation, under the conditions of variables not changing, the external reasons that affect the land prices of different areas and geographical locations can be determined.

\section{CONCLUSION}

This paper analyzes a major reason why the local government difficulty implements the policy which suppresses the land prices, meaning that the government will have to break the win-win scene and to also control the shift in the slope of the supply curve. As soon as the number of investors decreases, the supply curve will revert to an equilibrium state's slope. This economic phenomenon's effectiveness is not on regulating the supply, but is exclude speculators from purchasing parties. On the other hand, on top of redefining the benefits equilibrium, the benefits equilibrium baseline is found through the conclusion of the government's regulations on land prices (in mathematical terms). As for the new model, further studies will need to carry out error analysis and calibration of data. In the process of practical usage, further studies will also need to determine the multiple values of these variables.

TABLE1 THE MATHEMATICAL SIGNIFICANCE OF EACH VARIABLE AND CORRELATION COEFFICIENT IN THE MODEL OF THE COMMERCIAL LAND PRICE

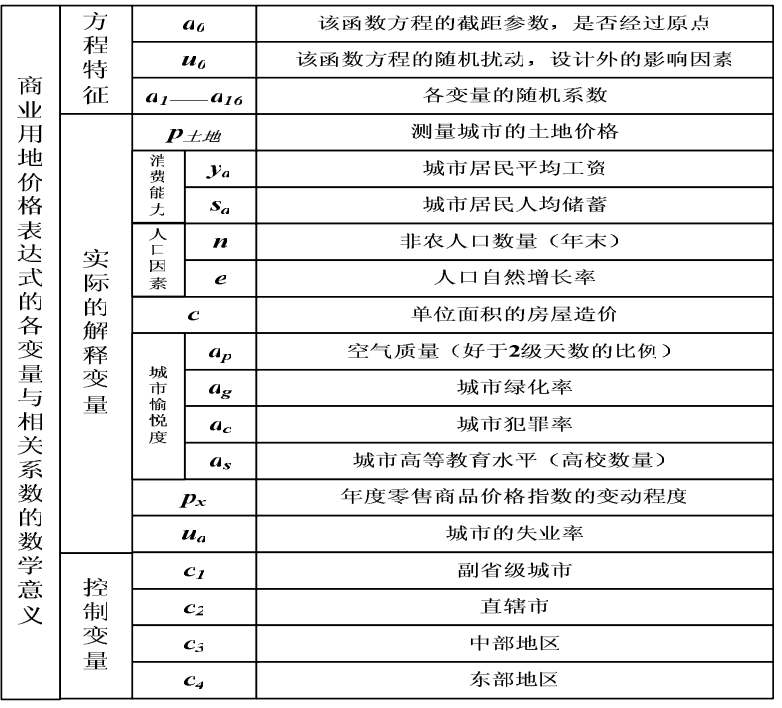

\section{REFERENCE}

[1] Muth, R. The derived demand for urban residential land [J].Urban Studies,1971,(8):51-66.

[2] Witte,A.D. The determination of interurban residential site Price differences: a derived demand model with empirical testing [J].Journal of Regional Science, 1975, (15):351- 364.

[3] Capozza,D.R. \& Li,Y.M. Residential investment and interest rate: an empirical test of land development as a real option [J]. Real Estate Economies,2001,29(3):503- 519.

[4] Capozza,D.R. \& Shilling, J.D. Introduction to the special issue [J]. Real Estate Economies,2005,33(l):l- 3.

[5] Davidoff,T. Labor income, housing prices, and home ownership [J]. Journal of Urban Economics, 2006, (59):209- 235

[6] Deation, A. \& Laroque, G. Housing, land prices, and growth [J]. Journal of Economics Growth,2001,(6):87- 105.

[7] Potepan, M. Explaining intermetropolitan variation in housing prices, rents and land prices [J]. Real Estate Economies,1996,(24):219- 245

[8] Meikle, N. \& Peng, L. Exploring metropolitan housing Price volatility [J]. Journal of Real Estate Finance and Economies,2006,(33):5- 18. 